\title{
Information
}

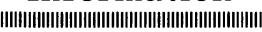

\section{Train-borne Measurements of Background Radiation along the Railways in New Zealand ${ }^{\dagger}$}

\author{
Susumu Minato and Shze Jer Hu* \\ National Industrial Research Institute of Nagoya \\ Hirate-machi, Kita-ku, Nagoya-shi 462-8510, Japan \\ *Universiti Brunei Darussalam \\ Bandar Seri Begawan BE1410, Negara Brunei Darussalam
}

\begin{abstract}
Key Words : terrestrial gamma-ray, cosmic-ray, dose rate, train-borne measurement, New Zealand
\end{abstract}

\section{Introduction}

Train-borne survey has been established as a technique to estimate in a short time the profile of the dose rates of environmental radiation over a very wide area. The collected data have been used variously : distinguishing man-made radiation from natural background levels ${ }^{1)}$, comparison with geology ${ }^{2)-5)}$ and distance-series analysis ${ }^{2), 6}$.

In this paper, we report a survey carried out recently in New Zealand to estimate the outdoor gamma-ray dose rates using a technique which is an improved version of one used previously in Australia $^{4}$. Bedrock data are presented for the convenience of geological analysis. Cosmic-ray dose rates estimated from atmospheric pressure data are also presented for those researchers who are interested in the total background radiation.

\section{Basic Techniques}

We performed the measurements using a con-

\footnotetext{
†ニュージーランド縦断鉄道浻線の環境放射線調

查。湊 進, 胡 雪 州*: 名古屋工業技術研究 所, 462-8510 名古屋市北区平手町 1-1, *ブル ネイ・ダルサラム大学, バンダル・スリ・ブガ ワン BE1410, ブルネイ。
}

ventional digital $\mathrm{NaI}(\mathrm{Tl})$ scintillation surveymeter on board regular service of passenger trains. This was convenient as no special arrangement need to be made beforehand.

One of the objectives of train-borne measurements is to examine the relationship between observed dose rate levels and geological features. This requires the exclusion of any variations due to topological changes like cliffs and tunnels. To this end, the topographic information was also noted down in a notebook along with the count rates. This is preferable to using an automatic recording system; it is difficult to include topographic information in an automated system.

\section{$2 \cdot 1$ Calibration}

A battery-operated portable type $1^{\prime \prime} \phi \times 2^{\prime \prime} \mathrm{NaI}$ (Tl) scintillation counter was used for the measurements. The conversion from count rates into absorbed dose rates in air has been calibrated earlier through simultaneous measurements with a $3^{\prime \prime} \phi \times 3^{\prime \prime} \mathrm{NaI}(\mathrm{Tl})$ scintillation spectrometer at different dose rate levels in a natural outdoor environment. The dose rates of the reference spectrometer were determined using the response matrix method ${ }^{7), 8)}$. 
Scintillation counters are sometimes used to evaluate background gamma-ray dose rates because the count rate can be converted into the dose rate with high accuracy if the contributions from man-made radionuclides are not significant. Assuming this to be the case, then the main cause of error in the conversion is expected to come from the variations in the ratio of uranium, thorium and potassium in the soil due to the differences in geological origins. For the instruments used, the statistical error in the conversion factor has been estimated to be around $4 \%$. The estimate was obtained from calculations done using 1000 sets of data of uranium, thorium and potassium concentrations collected from different areas of the world.

\section{$2 \cdot 2$ Conversion into outdoor values}

Usually, train-borne survey data are collected from inside the train. As such, the data may be considerably perturbed by some factors such as shielding by train bodies and ballasts and other structures along the railroads. In order to convert the measurements inside the train into outdoor dose rates, we use a regression line obtained from the comparison of train-borne survey data from different regions with the corresponding outdoor measurements made at various sites within the respective regions.

Figure 1 shows the comparison of the data obtained inside and outside the train. The outdoor data were taken by other researchers ${ }^{9)}{ }^{-12}$, while the inside data were from Refs. 2-5. As can be seen in the figure the agreement between them is not particularly good, probably because respective sampling sites for the train-borne data do not match very well those for the outdoor data. However, the figure does reveal some extent of correlation. The distribution of residuals (differences from the regression line) has a standard deviation

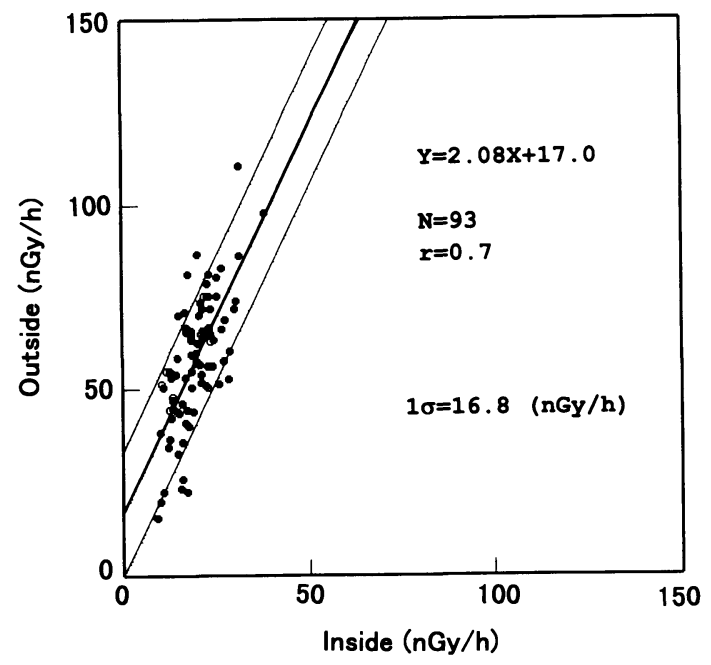

Fig. 1 Correlation of air absorbed dose rates inside trains to those measured outdoors.

The terms $N$ and $r$ represent the number of samples and a correlation coefficient, respectively.

of about $\pm 17 \mathrm{nGy} / \mathrm{h}$, as indicated by the thin lines in the figure. If the outdoor measurements had been made along the routes of the corresponding train-borne surveys, we probably would be able to obtain an error considerably less than the above value.

\subsection{Influence of cliffs, tunnels and waters}

In general, measurements taken while passing by a cliff or through a tunnel would show an increase compared to that of the level ground since the natural gamma-ray sources would subtend to a large solid angle at the detector. On the other hand, when passing over a big river or a lake or along the shoreline, the background level decreases because of the shielding effect of the water. However, in all these situations, because of the constant motion, it is usually difficult to determine the precise solid angles to calculate the corrections. Therefore, in this survey, the corrections were done by first, writing down the topographical conditions in a notebook adjacent to the cor- 
responding count rates as the latter were collected. Subsequently the increased or reduced components were removed by linear interpolation between the values measured at the two points immediately outside of the region occupied by the cliff and tunnel or the water body.

The criterion for deciding whether the influence of the cliff is significant or not was based on the following model calculations. Our model assumes that the cliff has infinite width and a constant height, whose angle of elevation seen at the detector placed normal to the cliff is denoted by $\theta$. Table 1 shows the values of the solid angle $\omega$ subtended at the detector for various values of $\theta$. The table also gives the percentage increase $(\omega /$ $2 \pi$ ) in the solid angle compared to a flat ground situation. We recorded the topographical information (cliff) only when $\theta$ was judged, visually through the train window, to be over 20 degrees.

\subsection{Estimation of cosmic-ray dose rates}

According to NCRP report ${ }^{13)}$, cosmic-ray intensities in New Zealand are at the same level as those in the United States. Therefore, we have used the theoretical data calculated by $O^{\prime} B$ rien $^{14)}$ for a geomagnetic latitude of $55^{\circ} \mathrm{N}$. The mean of the solar-maximum and solar-minimum dose rate

Table 1 Calculated solid angles as a function of angle of elevation

\begin{tabular}{ccc}
\hline$\theta$ & $\omega$ & $\omega / 2 \pi$ \\
$\left({ }^{\circ}\right)$ & $(\mathrm{sr})$ & $(\%)$ \\
\hline 0 & 0.00 & 0.0 \\
10 & 0.36 & 5.7 \\
20 & 0.71 & 11.2 \\
30 & 1.04 & 16.6 \\
40 & 1.40 & 22.2 \\
50 & 1.76 & 28.1 \\
60 & 2.11 & 33.6 \\
70 & 2.46 & 39.1 \\
80 & 2.81 & 44.7 \\
90 & 3.14 & 50.0 \\
\hline
\end{tabular}

values at various elevations is given by the empirical formula ${ }^{4}$ :

$$
J=31.6 \exp \left\{(1013 / P)^{1.70}-1\right\}
$$

where $J$ is the cosmic-ray absorbed dose rate in $\mathrm{nGy} / \mathrm{h}$ and $\boldsymbol{P}$ the pressure in $\mathrm{hPa}$. The formula is valid for a range from sea-level pressure up to about $900 \mathrm{hPa}$.

\section{Results and Discussion}

The survey was performed over a period of three days, starting from 22 till 24 February 1998. The survey route is shown in Fig. 2. The count rates and atmospheric pressures were measured inside the trains over a distance of $1617 \mathrm{~km}$. The first leg of measurements started at Invercargill, the southern most city of New Zealand and ended at Christchurch. The second leg of measurement continued from Christchurch the next day and ended at Picton. The last leg of measurement began at Wellington on the third day and ended at Auckland.

A one-dimensional distance-series comprising

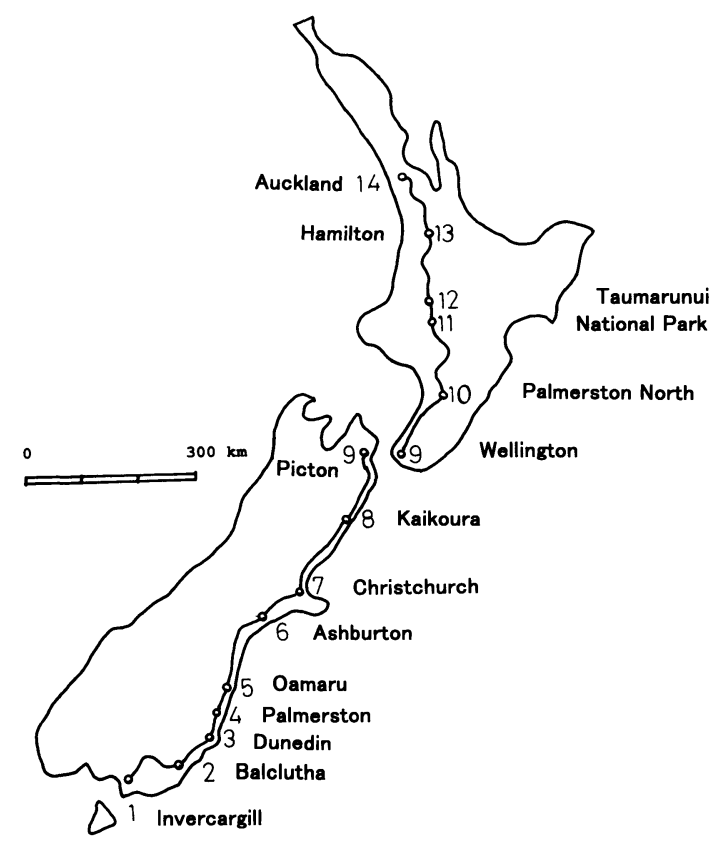

Fig. 2 Map showing the survey route. 


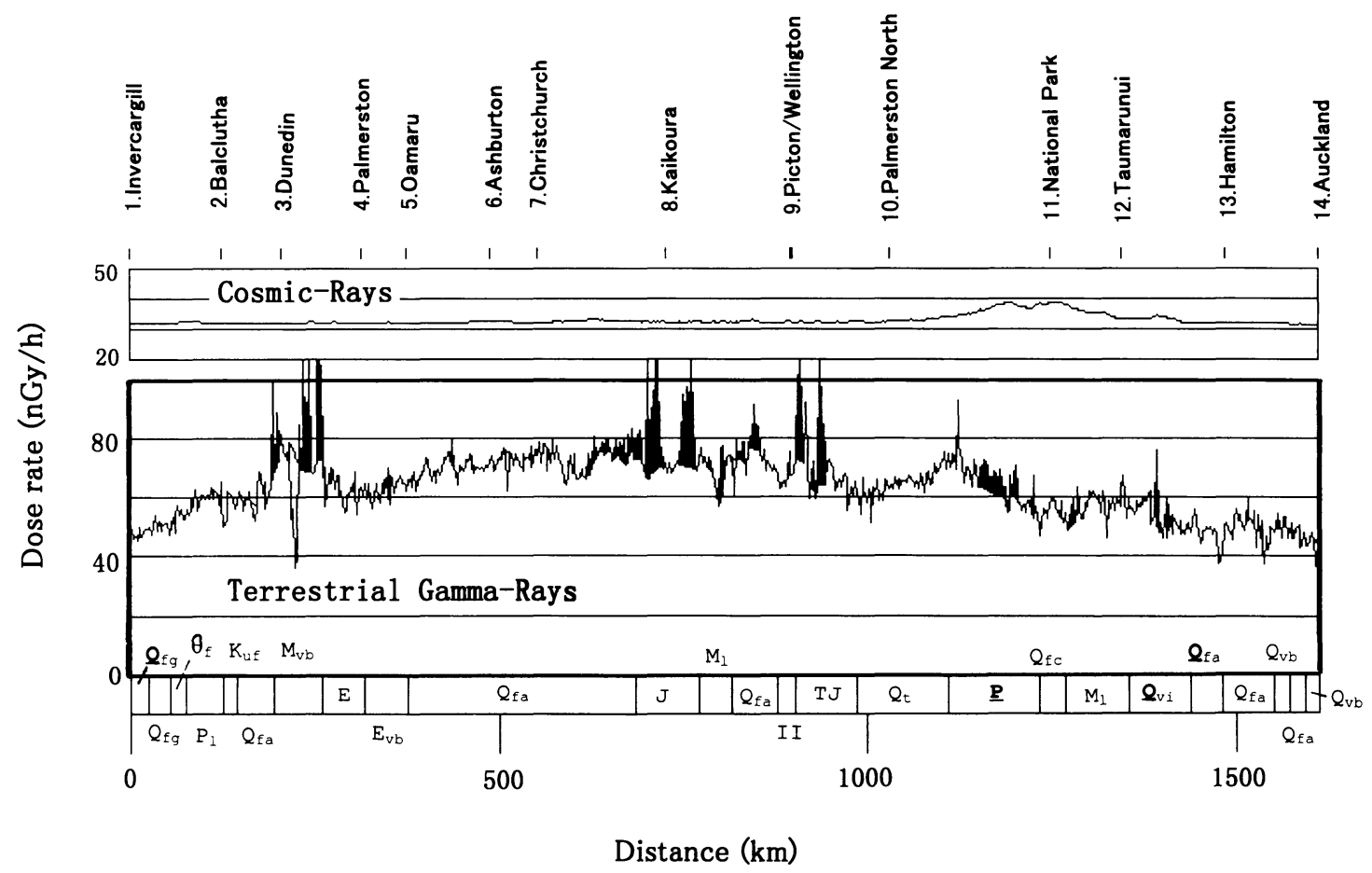

Fig. 3 Observed variation in air absorbed dose rate with distance.

761 data points was obtained. The reading was sampled every $2 \mathrm{~min}$. The measured data were corrected and converted using the techniques described in the preceding section, to yield outdoor equivalent dose rates above flat ground. The mean of the terrestrial gamma-ray dose rates is found to be $62.7 \mathrm{nGy} / \mathrm{h}$ with one standard deviation of 9.1 $\mathrm{nGy} / \mathrm{h}$. Figure 3 displays the data collected in this survey. The abbreviations given at the bottom of the figure represent geological features, the details of which are given in Table 2. The peaks in black are indication of increments due to the cliffs and tunnels. Near to Dunedin, the train followed closely the shoreline of a bay and this caused an abrupt decrease in the dose rate. Cliff-, tunnel-, and water-corrected data accounted for about $15 \%$ of the total data in this expedition.

To check the validity of our measurements, we compare the dose rates converted from the trainborne data at various localities with the corre- sponding outdoor measurements of nearby sites. Matthews ${ }^{15)}$ has calculated the terrestrial gammaray dose rates in New Zealand using the results from a nation-wide survey of the concentrations of natural radionuclides in soils. Figure 4 shows the comparison of our data with his. Matthews' data scatter almost within the statistical error of the present method. Thus, it appears justified to consider that the train-borne survey data on the whole represent the outdoor radiation levels fairly well.

\section{Acknowledgments}

We thank Mr. Tsuyoshi Minato for his help in the measurements. Several helpful discussions with Dr. Kai Kien Lai of Universiti Brunei Darussalam are also gratefully acknowlegded.

\section{References}

1) Okano, M.: Measuring radiation inside trains, 
Table 2 Geological features for the surveyed route

Q: Post-glacial marine, estuarine and coastal lagoonal deposit./Upper Quaternary.

$\left(Q_{t}\right)$ Marine deposits on coastal benches, locally with non-marine cover.

$\left(Q_{\mathrm{fa}}\right)$ Post-glacial alluvium.

$\left(Q_{\mathrm{fc}}\right)$ Laharic colluvium.

$\left(Q_{\mathrm{fg}}\right)$ Aggradation (mainly glacial) gravel.

$\left(Q_{\mathrm{vb}}\right)$ Basalt of volcanos, flows and scoria cones.

Q: $\quad$ Marine sandstone, siltstone, conglomerate./Lower Quaternary.

$\left(\mathbf{Q}_{\mathrm{fa}}\right)$ Alluvial sand and gravel of high inland terraces.

$\left(\mathbf{Q}_{\mathrm{fg}}\right)$ Piedmont gravel or conglomerate ; local glacial deposit on West coast.

$\left(\mathbf{Q}_{\mathrm{vi}}\right)$ Ignimbrite and associated ash-flow tuff, rhyolitic to dacitic.

$\left(\mathbf{Q}_{\mathrm{vb}}\right)$ Basalt of dissected volcanos and flows; agglomerate.

P : $\quad$ Marine sandstone, siltstone, conglomerate, coquina limestone./Pliocene.

M : Mainly sandstone and siltstone (locally alternating and graded); local limestone in Southland. /Miocene.

$\left(\mathrm{M}_{\mathrm{vb}}\right)$ Basalt, andesite, trachyte, phonolite, in sheets and flows, in east Otago; basalt, tuff, in Canterbury.

$\theta: \quad$ Mainly limestone and calcareous siltstone, commonly glauconitic; local limestone in Southland./Oligocene.

$\left(\theta_{\mathrm{f}}\right) \quad$ Coal measures.

E : Sandstone, siltstone; limestone, locally siliceous with basal flint beds, in Marlborough. /Eocene.

$\left(E_{\mathrm{vb}}\right)$ Basalt, pillow lava, tuff, in north Otago and Chatham Is.

$\mathrm{K}: \quad /$ Cretaceous.

$\left(\mathrm{K}_{\mathrm{uf}}\right)$ Coal measures, conglomerate.

$\mathrm{J}$ : Interbedded greywacke and argillite (greywacke graded in places); minor conglomerate, basaltic and spilitic volacanics, chert.

Sandstone, siltstone, conglomerate in southland./Jurassic.

T: Interbedded greywacke and argillite (greywacke graded in places); minor basaltic and spilitic volacanics, chert, rare limestone lenses./Triassic.

P: Greywacke and argillite, minor chert, volcanics, limestone, in south Canterbury. Metaconglomerate, biotite-garnet schist, quartzite, in west Nelson./Permian.

$\left(\mathrm{P}_{1}\right) \quad$ Argillite with spilitic volcanics and igneous conglomerate, in Nelson; greywacke and argillite, in south Otago.

Regionally-Metamorphosed Rocks.

II: Chlorite Zone quartzo-feldspathic semi-schist and schists; local piedmonite, stilpnomelane or actinolite; green schist band./Upper Paleozoic to Mid-Mesozoic.

Film Badge News, No. 177, 1-7 (1991), in Japanese

2) Minato, S.: Some properties of place-to-place variation in terrestrial gamma-ray flux observed along a transcontinental railway in North America, Nucl. Sci. J., 29, 107-117 (1992)

3) Lin, P-H., Liu, C-C., Chen, C-J., Lin, Y-M. and
Minato, S.: Train-borne survey of natural background radiation dose rates around Taiwan railway, ibid., 32, 260-266 (1995). in Chinese

4) Minato, S., Kodaira, K. and Ito, M.: A background radiation survey along the transcontinental railway in Australia, Radioisotopes, 44, 330334 (1995) 

A : Auckland (13 soil samples)
C : Christchurch (16)
D : Dunedin (25)
$\mathrm{H}:$ Hamilton (13)
I : Invercargill-Balclutha (13)
$\mathrm{K}:$ Kaikoura-Picton (5)
O : Oamaru (12)
$\mathrm{P}:$ Palmerston North (12)
$\mathrm{W}:$ Wellington (14)

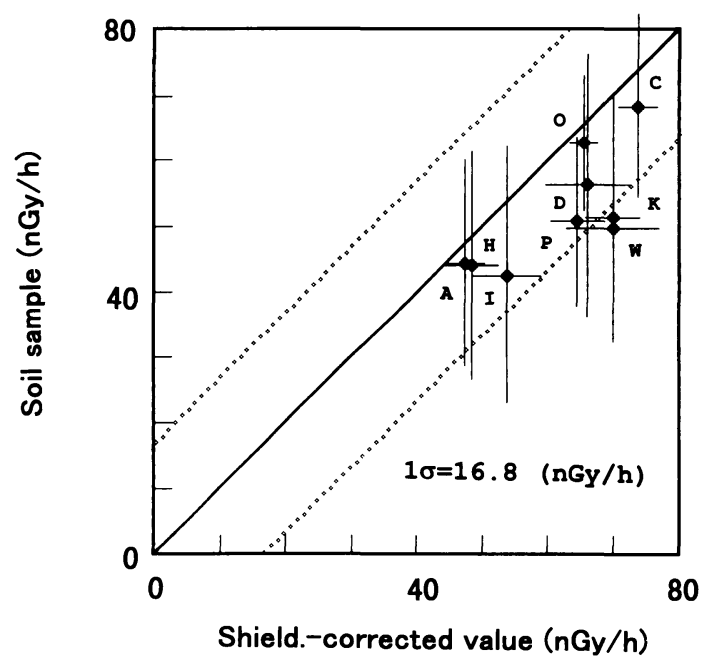

Fig. 4 Comparison of outdoor equivalent dose rates obtained by train-borne measurements to the values calculated from soil sample measurements ${ }^{15)}$.

5) Saelim, B., Lupu, A., Minato, S. and Kodaira, K.: A trian-borne survey of terrestrial gamma-ray dose rates in Shikoku, Proc. of 34 th Ann. Meeting on Radioisot. in Phys. Sci. \& Ind., 1, p-II-5 (1997)

6) Minato, S.: The structure of spatial fluctuation in terrestrial gamma-ray dose rate levels observed through one-dimensional surveys, Radioisotopes, 45, 619-625 (1996)
7) Minato, S. and Kawano, M.: Evaluation of exposure due to terrestrial gamma-radiation by response matrix method, J. Nucl. Sci. Technol., 7, 401-406 (1970)

8) Minato, S.: Analysis of environmental gamma-ray pulse-height distributions, JCAC Journal, No. 32, 2-13 (1998), in Japanese

9) Abe, S., Fujitaka, K., Abe, M. and Fujimoto, K.: Extensive field survey of natural radiation in Japan, J. Nucl. Sci. Technol., 18, 21-45 (1981)

10) NCRP Report No. 94: "Exposure of the population in the United States and Canada from natural background radiation", National Council on Radiation Protection and Measurements, (7910 Woodmont Avenue/Bethesda, MD 20814, USA, 1987)

11) Matsuura, S., Ninomiya, H., Yasunaga, S., Yano, T., Kaneko, T. and Yasui, M. : Natural radiation distribution in Ehime prefecture, Report of Ehime Prefectural Research Center for Environmental Protection, No. 3, 32-37 (1986), in Japanese

12) Lin, Y-M., Lin, P-H., Chen, C-J. and Huang, C-C.: Measurements of terrestrial $\gamma$ radiation in Taiwan, Republic of China, Health Phys., 805-811 (1987)

13) NCRP Report No. 50: "Environmental Radiation Measurements", National Council on Radiation Protection and Measurements, (7910 Woodmont Avenue/Washington, D. C. 20014, USA, 1976)

14) O'Brien, $\mathrm{K} .:$ The cosmic ray field at ground level, "The Natural Radiation Environment II", (Adams, J. A. S., Lowder, W. M. and Gesell, T. eds.) pp. 15-54, CONF-720805, U.S. Energy Research and Development Administration, Washington (1975)

15) Matthews, K. M.: Natural outdoor radiation exposure in New Zealand, N. Z. J. Sci., 20, 421-424 (1977) 